\title{
Amphiphilic Pentablock Copolymers and Their Blends with PDMS for Anti- biofouling Coatings
}

\author{
Elisa Martinelli*, Elisa Guazzelli, Cristina Bartoli, Matteo Gazzarri, Federica Chiellini, Giancarlo Galli* \\ Dipartimento di Chimica e Chimica Industriale, UdR Pisa INSTM, Università di Pisa, via G. Moruzzi 3, \\ 56124 Pisa, Italy \\ Maureen E. Callow, James A. Callow, John A. Finlay, Sophie Hill \\ School of Biosciences, University of Birmingham, Birmingham B15 2TT, UK
}

Correspondence to: giancarlo.galli@unipi.it, elimart79@dcci.unipi.it

\begin{abstract}
Well-defined amphiphilic pentablock copolymers Siy-(EGx-FAz) ${ }_{2}$ composed of polysiloxane (Si), polyethylene glycol (EG) and perfluorohexylethyl polyacrylate (FA) blocks are synthesized by ATRP of FA monomer starting from a difunctional bromo-terminated macroinitiator. Diblock copolymers EGx-FAz are also synthesized as model systems. The block copolymers are used, either alone or blended with a PDMS matrix in varied loadings, to prepare anti-biofouling coatings. Angleresolved XPS and contact angle measurements show that the coating surface is highly enriched in fluorine content but undergoes reconstruction after contact with water. Protein adsorption experiments with human serum albumin and calf serum highlight that diblock copolymers resist protein adhesion better than do pentablock copolymers. Blending of the pentablock copolymer with PDMS results in increased protein adsorption. By contrast, the PDMS-matrix coatings show high removal percentages of sporelings of the green fouling alga Ulva linza.
\end{abstract}

KEYWORDS: pentablock copolymer, amphiphilic polymer, fluorinated polymer, protein adsorption, anti-biofouling, Ulva linza

\section{INTRODUCTION}

Biofouling consists of the accumulation of proteins, cells and organisms on wet surfaces, widely ranging from ship hulls ${ }^{1}$ to membranes for water purification ${ }^{2}$ and to biomedical devices and implants. ${ }^{3,4}$ Notably, marine biofouling is a worldwide problem that imposes a major economic burden on maritime industries. ${ }^{5,6}$ Biocide-containing antifouling paints are effective in combating biofouling, ${ }^{7}$ but their use is becoming more restricted because of potential toxicity to the marine environment. ${ }^{8-10}$ Accordingly, in recent years more environmentally-friendly approaches have been pursued. The main aim is to replace 
traditional biocidal antifouling ( $\mathrm{AF}$ ) coatings, that prevent the settlement (attachment) of the colonising stages of fouling organisms, with fouling release (FR) coatings, that reduce the adhesion strength of organisms so that they are removed by hydrodynamic forces such as those generated as a ship moves through the water. ${ }^{11}$

Various strategies for producing novel AF/FR polymer coatings have been tested, including liquid crystalline copolymers with fluorinated side chains, ${ }^{12,13}$ perfluoropolyether networks, ${ }^{14}$ phasesegregated polysiloxane systems, ${ }^{15,16}$ zwitterionic polymers ${ }^{17}$ and polymer nanocomposites. ${ }^{18,19}$ Amphiphilic coatings, generally originated from the combination of a hydrophobic and a hydrophilic component, are also of crucial importance in this field. ${ }^{20}$ In particular, fluorinated polymers are highly hydrophobic, low surface energy materials capable of reducing polar and hydrogen-bonding interactions with the bioadhesives used by fouling organisms. On the other hand, polyethylene glycol (PEG) is a hydrosoluble and biocompatible polymer widely used in biomedical applications because of its ability to give rise to surfaces that resist protein adsorption. Amphiphilic coatings for AF/FR applications are produced by different strategies, including crosslinking of PEG with hyperbranched fluoropolymers, ${ }^{21,22}$ UV photo-crosslinking of mixtures containing PEG and fluorinated macromonomers, ${ }^{23}$ and dispersions of fluorinated/PEGylated surface-active copolymers within an elastomeric matrix, such as SEBS and PDMS. $^{24-28}$ The amphiphilic surfaces created exhibit mixed hydrophilic and hydrophobic functionalities and have local nanoscale heterogeneities that deter the settlement of organisms and also minimize the intermolecular forces of interaction between biomolecules and substratum. ${ }^{23,29,30}$ Moreover, the elastomer matrix provides independent control of the elastic property of the entire coating, an attribute that has been shown to be important for FR performance. ${ }^{31-33}$ The most environmentally benign FR coatings currently commercialised are those based on PDMS elastomers. ${ }^{20}$

Combinations of those pre-requisite features into effective anti-biofouling polymer systems in many cases are achieved by complex chemical platforms that involve e.g. sequential polymerizations of specifically synthesized monomers and series of polymer-analogue modifications of preformed polymers. In this work we explored a new facile route to develop anti-biofouling coatings based on novel amphiphilic pentablock copolymers with an ABCBA structure composed of a hydrophobic polysiloxane block (C), two hydrophilic polyethylene glycol blocks (B) and two hydrophobic/lipophobic fluorinated polyacrylate blocks (FA). Diblock copolymers with a BA structure, i.e. not containing a siloxane block, were also synthesized as model polymers for comparison. Thanks to the presence of the siloxane central block, the pentablock copolymers could be incorporated into a crosslinked PDMS matrix for production of robust coatings with anti-biofouling potential. Protein adsorption experiments were carried out with 
a single protein, viz human serum albumin, and a consortium of proteins (calf serum). AF and FR performances were tested in laboratory bioassays with zoospores and sporelings (young plants) of the marine macroalga Ulva linza. It is shown that the PDMS-matrix coatings containing amphiphilic pentablock copolymers may serve as marine fouling release coatings.

\section{EXPERIMENTAL}

\section{Materials}

Trifluorotoluene (TFT, Sigma-Aldrich), chlorotrimethyl silane (Sigma-Aldrich) and bismuth neodecanoate (BiND, Sigma-Aldrich) were used as received. CuBr (Sigma-Aldrich) was purified by washing with glacial acetic acid followed by diethyl ether, dried under vacuum and stored under nitrogen. 2-Bromoisobutyryl bromide (BIBB, Sigma-Aldrich), $N, N, N^{\prime}, N^{\prime \prime}, N^{\prime \prime}$-pentamethyldiethylenetriamine (PMDETA, Sigma-Aldrich), triethylamine (TEA, Sigma-Aldrich), tetrahydrofuran (THF, Sigma-Aldrich) and anisole (Sigma-Aldrich) were distilled and stored under nitrogen. Perfluorohexylethyl acrylate (FA, Fluoryx) was passed through a basic alumina column to remove inhibitors before use. Two poly(ethylene glycol) monomethyl ethers

(EGXOH) $M_{\mathrm{n}}=550 \mathrm{~g} \mathrm{~mol}^{-1}, x=12$, and $M_{\mathrm{n}}=2000 \mathrm{~g} \mathrm{~mol}^{-1}, x=46$, Sigma-Aldrich) were dried by azeotropic distillation with toluene. Dihydroxyl-terminated polyethylene glycol-b-polydimethyl siloxane- $b$ polyethylene glycol triblock copolymer $(A B C R)$ was purified by precipitations from chloroform solutions in $n$-hexane to obtain a final product Si5-(EG7OH $)_{2}\left(M_{\mathrm{n}}=1100 \mathrm{~g} \mathrm{~mol}^{-1}\right)$. Poly(diethoxy siloxane) (ES40, $M_{\mathrm{n}}=134 \mathrm{~g} \mathrm{~mol}^{-1}, \mathrm{ABCR}$ ), and disilanol-terminated poly(dimethyl siloxane) (HO-PDMS-OH, $0.1 \% \mathrm{OH}, M_{\mathrm{n}}=$ $\left.26000 \mathrm{~g} \mathrm{~mol}^{-1}, \mathrm{ABCR}\right)$ were used as received.

\section{Copolymer synthesis}

\section{Preparation of monofunctional macroinitiators}

As one example, a solution of BIBB $(3.471 \mathrm{~g}, 15.10 \mathrm{mmol})$ in $15 \mathrm{~mL}$ of THF was slowly added to a solution of EG12OH (5.299 g, $9.20 \mathrm{mmol})$ and TEA $(1.528 \mathrm{~g}, 15.10 \mathrm{mmol})$ in $75 \mathrm{~mL}$ of THF. The reaction was kept at room temperature for $24 \mathrm{~h}$ under vigorous stirring. The bromide salt precipitated was filtered and the solvent was removed under vacuum. The crude product was purified by precipitations from THF solutions in $n$-hexane. The resulting macroinitiator (yield $71 \%)\left(M_{\mathrm{n}}=550 \mathrm{~g} \mathrm{~mol}^{-1}, x=12\right)$ is denoted as $\mathrm{EG} 12 \mathrm{Br}$.

${ }^{1} \mathrm{H} \mathrm{NMR}\left(\mathrm{CDCl}_{3}, \delta\right.$ in ppm): $4.3\left(2.0 \mathrm{H}, \mathrm{COOCH}_{2}\right), 3.3\left(3.0 \mathrm{H}, \mathrm{OCH}_{3}\right), 3.4-3.8\left(46.0 \mathrm{H}, \mathrm{OCH}_{2} \mathrm{CH}_{2}\right), 1.9(6.0 \mathrm{H}$, $\left.\mathrm{C}\left(\mathrm{CH}_{3}\right)_{2}\right)$. 
FT-IR (KBr pellet, $\bar{v}$ in $\mathrm{cm}^{-1}$ ): 2873 (v C-H aliphatic), 1734 (v C=O ester), 1462 ( $\delta$ C-H aliphatic), 1167-1037 ( $v$ C-O).

\section{Preparation of difunctional macroinitiators}

As one example, a solution of BIBB $(5.729 \mathrm{~g}, 24.92 \mathrm{mmol})$ in $15 \mathrm{~mL}$ of THF was slowly added to a solution of Si5-(EG7OH $)_{2}(6.878 \mathrm{~g}, 6.23 \mathrm{mmol})$ and TEA $(2.521 \mathrm{~g}, 24.92 \mathrm{mmol})$ in $70 \mathrm{~mL}$ of THF. The reaction was kept at room temperature for $24 \mathrm{~h}$ under vigorous stirring. The bromide salt precipitated was filtered and the solvent was removed under vacuum. The crude product was purified by precipitations from chloroform in $n$-hexane. The resulting macroinitiator (yield 39\%) $\left(M_{\mathrm{n}}=1400 \mathrm{~g} \mathrm{~mol}^{-1}, x=7, y=5\right)$ is denoted as Si5-(EG7Br) 2 .

${ }^{1} \mathrm{H}$ NMR $\left(\mathrm{CDCl}_{3}, \delta\right.$ in ppm): $4.3\left(4.0 \mathrm{H}, \mathrm{COOCH}_{2}\right), 3.5-3.8\left(52.0 \mathrm{H}, \mathrm{OCH}_{2} \mathrm{CH}_{2}\right), 3.4\left(4.0 \mathrm{H}, \mathrm{OCH}_{2} \mathrm{CH}_{2} \mathrm{CH}_{2}\right), 1.9$ $\left(12.0 \mathrm{H}, \mathrm{C}\left(\mathrm{CH}_{3}\right)_{2}\right), 1.6\left(4.0 \mathrm{H}, \mathrm{SiCH}_{2} \mathrm{CH}_{2} \mathrm{CH}_{2} \mathrm{O}\right), 0.5\left(4.0 \mathrm{H}, \mathrm{SiCH}_{2} \mathrm{CH}_{2} \mathrm{CH}_{2} \mathrm{O}\right), 0.1\left(30.0 \mathrm{H}, \mathrm{Si}\left(\mathrm{CH}_{3}\right)_{2}\right)$.

FT-IR ( $\mathrm{KBr}$ pellet, $\bar{v}$ in $\mathrm{cm}^{-1}$ ): 2958-2870 ( $v \mathrm{C}-\mathrm{H}$ aliphatic), 1736 (v C=O ester), 1463 ( $\delta \mathrm{C}-\mathrm{H}$ aliphatic), 1260 and 804 ( v Si-CH $), 1167-1023$ (v C-O, v Si-O).

\section{Preparation of diblock copolymers}

As one example, EG12Br (0.433 g, $0.61 \mathrm{mmol}), \mathrm{FA}(2.567 \mathrm{~g}, 6.14 \mathrm{mmol}), \operatorname{PMDETA}(0.106 \mathrm{~g}, 0.61 \mathrm{mmol})$ and $6 \mathrm{~mL}$ of solvent (anisole/TFT 1:1 v/v) were introduced in a schlenk tube and degassed with 4 freezepump-thaw cycles. Then $\mathrm{CuBr}(88.1 \mathrm{mg}, 0.61 \mathrm{mmol})$ was added and after 3 freeze-pump-thaw cycles the polymerization was left to proceed for $12 \mathrm{~h}$ at $115{ }^{\circ} \mathrm{C}$ under nitrogen atmosphere. The polymer was purified by repeated precipitations from chloroform into methanol (yield 57\%). The number average degree of polymerization of the FA block ( $z$ ) was 9 and the diblock copolymer is named EG12-FA9.

${ }^{1} \mathrm{H}$ NMR $\left(\mathrm{CDCl}_{3}, \delta\right.$ in ppm): 4.1-4.5 $\left(20.0 \mathrm{H}, \mathrm{COOCH}_{2}\right), 3.5-3.8\left(46.0 \mathrm{H}, \mathrm{OCH}_{2} \mathrm{CH}_{2}\right), 3.4\left(3.0 \mathrm{H}, \mathrm{OCH}_{3}\right)$, 2.1-2.5 (18.0 $\left.\mathrm{H} \mathrm{CF}_{2} \mathrm{CH}_{2}\right), 1.0-2.1\left(33.0 \mathrm{H}, \mathrm{C}\left(\mathrm{CH}_{3}\right)_{2}, \mathrm{CH}_{2} \mathrm{CH}\right)$.

${ }^{19} \mathrm{~F} \mathrm{NMR}\left(\mathrm{CDCl}_{3} / \mathrm{C}_{6} \mathrm{~F}_{6}, \mathrm{CF}_{3} \mathrm{COOH}, \delta\right.$ in ppm): $-5.5\left(3.0 \mathrm{~F}, \mathrm{CF}_{3}\right),-38.5\left(2.0 \mathrm{~F}, \mathrm{CF}_{2} \mathrm{CH}_{2}\right),-46.0$ to -48.0 (6.0 F, $\left.\mathrm{CF}_{2}\right),-51.0\left(2.0 \mathrm{~F}, \mathrm{CF}_{2} \mathrm{CF}_{3}\right)$.

FT-IR ( $\mathrm{KBr}$ pellet, $\bar{v}$ in $\mathrm{cm}^{-1}$ ): 2954-2877 (v C-H aliphatic), 1739 (v C=O ester), 1455 ( $\delta$ C-H aliphatic), 1237-1083 (v C-F, v C-O), $652\left(\omega \mathrm{CF}_{2}\right)$.

Otherwise for samples EG46-FAz, the copolymer was firstly precipitated in $n$-hexane, then dissolved in chloroform and passed through a basic alumina column to remove catalyst residues. Finally, the polymer was purified by repeated precipitations from chloroform solutions into $n$-hexane. For EG46-FA9: 
${ }^{1} \mathrm{H}$ NMR $\left(\mathrm{CDCl}_{3}, \delta\right.$ in ppm): 4.1-4.5 $\left(20.0 \mathrm{H}, \mathrm{COOCH}_{2}\right), 3.5-3.8\left(182.0 \mathrm{H}, \mathrm{OCH}_{2} \mathrm{CH}_{2}\right), 3.4\left(3.0 \mathrm{H}, \mathrm{OCH}_{3}\right)$, 2.1-2.5 (18.0 $\left.\mathrm{H} \mathrm{CF}_{2} \mathrm{CH}_{2}\right), 1.0-2.1\left(33.0 \mathrm{H}, \mathrm{C}\left(\mathrm{CH}_{3}\right)_{2}, \mathrm{CH}_{2} \mathrm{CH}\right)$.

${ }^{19} \mathrm{~F} \mathrm{NMR}\left(\mathrm{CDCl}_{3} / \mathrm{C}_{6} \mathrm{~F}_{6}, \mathrm{CF}_{3} \mathrm{COOH}, \delta\right.$ in ppm): $-5.5\left(3.0 \mathrm{~F}, \mathrm{CF}_{3}\right),-38.5\left(2.0 \mathrm{~F}, \mathrm{CF}_{2} \mathrm{CH}_{2}\right),-46.0$ to $-48.0(6.0 \mathrm{~F}$, $\left.\mathrm{CF}_{2}\right),-51\left(2.0 \mathrm{~F}, \mathrm{CF}_{2} \mathrm{CF}_{3}\right)$.

FT-IR ( $\mathrm{KBr}$ pellet, $\bar{v}$ in $\mathrm{cm}^{-1}$ ): 2945-2800 (v C-H aliphatic), 1740 (v C=O ester), 1467 ( $\delta$ C-H aliphatic), 1236-1061 (v C-F, v C-O), $652\left(\omega \mathrm{CF}_{2}\right)$.

\section{Preparation of pentablock copolymers}

As one example, Si5-(EG7Br) 2 (0.515 g, $0.37 \mathrm{mmol}), \mathrm{FA}(2.475 \mathrm{~g}, 5.92 \mathrm{mmol}), \operatorname{PMDETA}(0.127 \mathrm{~g}, 0.73$ $\mathrm{mmol}$ ) and $6 \mathrm{~mL}$ of solvent (anisole/TFT 1:1 v/v) were introduced in a schlenk tube and degassed with 4 freeze-pump-thaw cycles. Then $\mathrm{CuBr}(105.3 \mathrm{mg}, 0.73 \mathrm{mmol})$ was added and after 3 freeze-pump-thaw cycles the polymerization was allowed to proceed for $24 \mathrm{~h}$ at $115^{\circ} \mathrm{C}$ in nitrogen inert atmosphere. The polymer was purified by repeated precipitations from chloroform into methanol (yield $48 \%$ ). The number average degree of polymerization of each FA block $(z)$ was 5 and the pentablock copolymer is named Si5-(EG7-FA5) 2 .

${ }^{1} \mathrm{H}$ NMR $\left(\mathrm{CDCl}_{3}, \delta\right.$ in ppm): 4.1-4.5 $\left(24.0 \mathrm{H}, \mathrm{COOCH}_{2}\right), 3.5-3.8\left(52.0 \mathrm{H}, \mathrm{OCH}_{2} \mathrm{CH}_{2}\right), 3.4(4.0 \mathrm{H}$, OCH $\left.\mathrm{CH}_{2} \mathrm{CH}_{2}\right), 2.1-2.6\left(20.0 \mathrm{H} \mathrm{CF}_{2} \mathrm{CH}_{2}\right), 1.1-2.1\left(46.0 \mathrm{H}, \mathrm{C}\left(\mathrm{CH}_{3}\right)_{2}, \mathrm{SiCH}_{2} \mathrm{CH}_{2} \mathrm{CH}_{2} \mathrm{O}, \mathrm{CH}_{2} \mathrm{CH}\right), 0.5(4.0 \mathrm{H}$, $\left.\mathrm{SiC} \mathrm{H}_{2} \mathrm{CH}_{2} \mathrm{CH}_{2} \mathrm{O}\right), 0.1\left(30.0 \mathrm{H}, \mathrm{Si}\left(\mathrm{CH}_{3}\right)_{2}\right)$.

${ }^{19} \mathrm{~F} \mathrm{NMR}\left(\mathrm{CDCl}_{3} / \mathrm{C}_{6} \mathrm{~F}_{6}, \mathrm{CF}_{3} \mathrm{COOH}, \delta\right.$ in ppm): $-5.5\left(3 \mathrm{~F}, \mathrm{CF}_{3}\right),-38.5\left(2 \mathrm{~F}, \mathrm{CF}_{2} \mathrm{CH}_{2}\right),-46.0$ to $-48.0\left(6 \mathrm{~F}, \mathrm{CF}_{2}\right)$, $-51.0\left(2 \mathrm{~F}, \mathrm{CF}_{2} \mathrm{CF}_{3}\right)$.

FT-IR ( $\mathrm{KBr}$ pellet, $\bar{v}$ in $\mathrm{cm}^{-1}$ ): 2961-2872 (v C-H aliphatic), 1741 (v C=O ester), 1458 ( $\delta$ C-H aliphatic), 1319-1065 (v Si-CH3, v C-F, v C-O, v Si-O), 809 (v Si-CH3), 652 ( $\omega \mathrm{CF}_{2}$ ).

\section{Preparation of PDMS-matrix coatings and copolymer films}

Squared $\left(76 \times 26 \mathrm{~mm}^{2}\right.$ or $\left.18 \times 18 \mathrm{~mm}^{2}\right)$ and round (16 mm diameter) glass slides were cleaned with acetone and dried in oven for $30 \mathrm{~min}$.

Two-layer PDMS-matrix coatings: A solution of HO-PDMS-OH (5.0 g), ES40 (0.125 g) and BiND (50 mg) in ethyl acetate $(25 \mathrm{~mL}$ ) was spray-coated on glass slides using a Badger model 250 airbrush (50 psi air pressure). The films were dried at room temperature for a day and annealed at $120^{\circ} \mathrm{C}$ for $12 \mathrm{~h}$ to form a thin layer $(\sim 2 \mu \mathrm{m})$. Onto it a solution of the same amounts of HO-PDMS-OH, ES40 and BiND was cast and cured at room temperature for a day and later at $120^{\circ} \mathrm{C}$ for $12 \mathrm{~h}$ to give a thicker bottom layer ( 150$200 \mu \mathrm{m})$. Subsequently, a top layer $(\sim 2 \mu \mathrm{m})$ was formed by spray-coating the same solution containing 
HO-PDMS-OH, ES40, BiND and the pentablock copolymer. The coatings were finally cured at room temperature for $12 \mathrm{~h}$ and then at $120^{\circ} \mathrm{C}$ for $12 \mathrm{~h}$.

The two pentablock copolymers Si5-(EG7-FA5) ${ }_{2}$ and $\mathrm{Si5}-(\mathrm{EG} 7-\mathrm{FA} 10)_{2}$ and the corresponding macroinitiator $\mathrm{Si5}-(\mathrm{EG7Br})_{2}$ were used to prepare three sets of two-layer coatings, Si5-(EG7-FA5) 2 wT, Si5-(EG7-FA10 $)_{2} w T$ and Si5-(EG7Br) $2_{2} w T$ with two loadings $w$ of the block copolymer in the top layer $(w$ $=4$ and 8 wt $\%$ copolymer with respect to PDMS).

One-layer PDMS-matrix coatings: A solution of HO-PDMS-OH (5.0 g), ES40 (0.125 g), BiND (50 mg) and block copolymer in ethyl acetate $(25 \mathrm{~mL})$ was spin-coated $(5000 \mathrm{rpm})$ on chlorotrimethylsilanefunctionalized glass slides. The coatings were finally cured at room temperature for $12 \mathrm{~h}$ and then at 120 ${ }^{\circ} \mathrm{C}$ for $12 \mathrm{~h}$ (thickness $\sim 500 \mathrm{~nm}$ ).

The two pentablock copolymers Si5-(EG7-FA5) ${ }_{2}$ and Si5-(EG7-FA10) $)_{2}$ were used to prepare two sets of one-layer coatings, Si5-(EG7-FA5) 2_wO and Si5-(EG7-FA10) 2_wO with two loadings $w$ of the block copolymer ( $w=4$ and $8 w t \%$ copolymer with respect to PDMS).

Block copolymer films: A 20\% (wt/v) TFT solution of each block copolymer was spin-coated on chlorotrimethylsilane-functionalized glass slides to obtain thin polymer films (thickness $\sim 500 \mathrm{~nm}$ ).

PDMS controls: Two-layer and one-layer coatings consisting of the PDMS matrix alone were also prepared as controls according to the above procedures.

\section{Characterization}

${ }^{1} \mathrm{H}$ NMR (vs $\mathrm{CHCl}_{3}$ ) and ${ }^{19} \mathrm{~F}$ NMR (vs $\mathrm{CF}_{3} \mathrm{COOH}$ ) spectra were recorded with a Varian Gemini VRX300 spectrometer. The number and weight average molecular weights of the polymers $\left(M_{\mathrm{n}}\right.$ and $\left.M_{\mathrm{w}}\right)$ were determined by size exclusion chromatography (SEC) with a Jasco PU-1580 liquid chromatograph equipped with two PL gel $5 \mu \mathrm{m}$ Mixed-D columns and a Jasco 830-RI refractive index detector. Poly(methyl methacrylate) standards (from $1160 \mathrm{~g} \mathrm{~mol}^{-1}$ to $124300 \mathrm{~g} \mathrm{~mol}^{-1}$ ) were used for calibration.

Differential scanning calorimetry (DSC) analysis was performed with a Mettler DSC-30 instrument from 160 to $100{ }^{\circ} \mathrm{C}$ at heating/cooling rate of $10{ }^{\circ} \mathrm{C} / \mathrm{min}$ under a dry nitrogen flow on 10-15 mg samples. The glass transition temperature $\left(T_{\mathrm{g}}\right)$ was taken as the inflection temperature in the second heating cycle. The melting temperature $\left(T_{m}\right)$ was taken as the minimum of the endothermic phase transition; the associated enthalpy was evaluated by peak integration with indium calibration.

Dynamic light scattering (DLS) measurements were performed using a Beckman Coulter-Delsa Nano C analyzer, equipped with $30 \mathrm{~mW}$ laser diodes (wavelength: $658 \mathrm{~nm}$ ) at $20^{\circ} \mathrm{C}$. The measuring angle was $166.2^{\circ}$. The data were analyzed by CONTIN fitting method. 
Contact angles $\theta$ were measured using the sessile drop method with a Camtel FTA200 goniometer at room temperature. Three interrogating liquids (water, isopropanol, and $n$-hexadecane) of different surface tensions $\left(\gamma_{L}\right)$ (purity $>99 \%$, Sigma-Aldrich) were used on films before and after immersion in water for a maximum time of 7 days. The contact angle values with water $\left(\theta_{\mathrm{w}}\right)$ and $n$-hexadecane $\left(\theta_{\mathrm{h}}\right)$ were then used to determine the surface tension $\left(\gamma_{s}\right)$ of the polymer films using the Owens-WendtKaelble approach. ${ }^{34,35}$

X-ray photoelectron spectroscopy (XPS) spectra were recorded by using a Perkin-Elmer PHI 5600 spectrometer with a standard Al-Ka source $(1486.6 \mathrm{eV})$ operating at $350 \mathrm{~W}$. The working pressure was less than $10^{-8} \mathrm{~Pa}$. The spectrometer was calibrated by assuming the binding energy (BE) of the $\mathrm{Au} 4 \mathrm{f}_{7 / 2}$ line to be $84.0 \mathrm{eV}$ with respect to the Fermi level. Extended (survey) spectra were collected in the range 0-1350 eV (187.85 eV pass energy, $0.4 \mathrm{eV}$ step, $0.05 \mathrm{~s} \mathrm{step}^{-1}$ ). Detailed spectra were recorded for the following regions: $\mathrm{C}(1 \mathrm{~s}), \mathrm{O}(1 \mathrm{~s}), \mathrm{F}(1 \mathrm{~s})$ and $\mathrm{Si}(2 \mathrm{p})\left(11.75 \mathrm{eV}\right.$ pass energy, $0.1 \mathrm{eV}$ step, $0.1 \mathrm{eV} \mathrm{s}$ step $\left.^{-1}\right)$. The standard deviation (SD) in the BE values of the XPS line was $0.10 \mathrm{eV}$. The atomic percentage, after a Shirley type background subtraction, ${ }^{36}$ was evaluated using the $\mathrm{PHI}$ sensitivity factors. ${ }^{37}$ To take into account charging problems, the C (1s) peak was considered at $285.0 \mathrm{eV}$ and the peak BE differences were evaluated.

\section{Protein adsorption experiments}

Human serum albumin (HSA) and calf serum were dissolved in phosphate buffer solution (PBS), $0.01 \mathrm{M}$ $\mathrm{pH} 7.4$, with concentrations of $70 \mu \mathrm{g} \mathrm{m}^{-1}$ and $35 \mu \mathrm{g} \mathrm{mL}^{-1}$, respectively. Polymer films and control glass slides were placed in polypropylene tubes and immersed in $2 \mathrm{~mL}$ of each protein solution for $2 \mathrm{~h}$ at 37 ${ }^{\circ} \mathrm{C}$. PBS was used as the blanking solution. The adsorption of HSA and serum proteins onto film surfaces was indirectly quantified by associating the depletion method with a colorimetric assay. The amount of protein in the supernatant was quantified using the Micro-Bicinchoninic Acid Kit (Pierce) and reading the visible absorbance $(565 \mathrm{~nm})$ in a microplate reader.

In order to qualitatively visualize the protein distribution on the film surfaces, samples were incubated in a solution of fluorescein isothiocyanate-labeled HSA (FITC-HSA) dissolved in PBS pH 7.4, for $2 \mathrm{~h}$ in the dark at $37^{\circ} \mathrm{C}$. Samples were subsequently observed with a Nikon Eclipse TE2000 inverted microscope equipped with an EZ-C1 confocal laser (Nikon) and Differential Interference Contrast (DIC) apparatus, with a $20 \times$ objective. An argon ion laser (488 nm emission) was used to excite FITC fluorophore. The images were captured with Nikon EZ-C1 software. 
Tests were performed on triplicate for each sample, and the data are presented as mean \pm standard deviation. Statistical difference was analyzed using one-way analysis of variance (ANOVA). A $p$ value $<$ $0.05(*)$ and $p$ value $<0.001(* *)$ were considered significant.

\section{Assays with Ulva linza}

Nine coated slides of each sample were placed in a $30 \mathrm{~L}$ tank of recirculating deionized water at $\sim 20{ }^{\circ} \mathrm{C}$ for 7 days. Samples were equilibrated with filtered $(0.22 \mu \mathrm{m})$ artificial seawater (ASW: $\operatorname{Tropic}^{\text {Marin }}{ }^{\circledR}$ ) for $1 \mathrm{~h}$ prior to the start of the bioassays. Zoospores were released into ASW from mature plants of $U$. linza using a standard method. ${ }^{38,39}$ In brief, $10 \mathrm{~mL}$ of zoospore suspension, adjusted to $1 \times 10^{6}$ spores $\mathrm{mL}^{-1}$ with ASW, were added to each test surface placed in individual compartments of Quadriperm dishes (Greiner One), which were placed in darkness at room temperature. After $45 \mathrm{~min}$, the slides were washed in filtered ASW to remove unsettled (unattached) zoospores. Three replicate slides of each sample were fixed in $2.5 \%$ glutaraldehyde in ASW then washed sequentially in filtered ASW, 50\% filtered ASW $/ 50 \%$ deionised water and deionised water and allowed to air-dry overnight. The density of adhered spores was determined by autofluorescence of chlorophyll using an AxioVision 4 image analysis system attached to a Zeiss fluorescence microscope (20x objective; excitation $546 \mathrm{~nm}$, emission $590 \mathrm{~nm}$ ). The reported data are the average of 90 counts, 30 counts from each of the three replicate slides (each 0.15 $\mathrm{mm}^{2}$ ). Resulting error bars show $95 \%$ confidence limits.

The six remaining slides of each sample were used to cultivate sporelings (young plants) of $U$. linza. Ten millilitres of nutrient-enriched $\mathrm{ASW}^{40}$ were added to each compartment of the Quadriperm dishes, which were incubated at $18{ }^{\circ} \mathrm{C}$ for 7 days with a $16 \mathrm{~h}: 8 \mathrm{~h}$ light:dark cycle and an irradiance of $40 \mu \mathrm{mol} \mathrm{m}{ }^{-}$ ${ }^{2} \mathrm{~s}^{-1}$. The ASW medium was refreshed every two days. The biomass of sporelings was determined in situ by measuring the fluorescence of the chlorophyll contained within the cells with a fluorescence plate reader (Tecan Genios Plus). The biomass was quantified in terms of relative fluorescence units (RFU). ${ }^{41}$ The strength of attachment of sporelings was determined using a calibrated flow channel ${ }^{42}$ in which the slides were exposed to a wall shear stress of $13 \mathrm{~Pa}$. Percentage removal was calculated from readings taken before and after exposure to flow, with 95\% confidence limits calculated from arcsinetransformed data.

Differences between surfaces were tested using one-way ANOVA followed by Tukey's test for pairwise comparisons. $^{41}$

\section{RESULTS AND DISCUSSION}


Diblock and pentablock copolymers were synthesized following two two-step procedures from macroinitiators (Schemes 1 and 2).

Firstly, bromo-terminated macroinitiators, $\mathrm{EG} x \mathrm{Br}$ and Siy- $(\mathrm{EG} \times \mathrm{Br})_{2}$, were prepared according to a general method $^{43}$ which involved the esterification reaction of commercially available polyethylene glycol precursors with BIBB in THF solution with TEA as a base. In particular, two polyethylene glycol monomethyl ethers $\mathrm{EGxOH}$ (number average polymerization degrees $x=12$ and 46 , respectively) were used for the synthesis of diblock copolymers (Scheme 1). A triblock copolymer Siy-(EGxOH $)_{2}$ with a symmetrical structure, composed of a polysiloxane central block (Si) (number average polymerization degree $y=5$ ) and two lateral polyethylene glycol blocks (EG) (number average polymerization degree $x=$ 7) was used for the preparation of pentablock copolymers (Scheme 2). Secondly, the macroinitiators were used for the ATRP of the perfluorohexylethyl acrylate (FA) monomer. In any case, the ATRP of FA was carried out at $115{ }^{\circ} \mathrm{C}$ using $\mathrm{CuBr}$ as catalyst, PMDETA as ligand and TFT/anisole $(1: 1 \mathrm{v} / \mathrm{v})$ as solvent (Table 1). The resulting pentablock copolymers were denoted as Siy-(EGx-FAz)$)_{2}$ where $x, y$ and $z$ are the number average polymerization degrees of EG, Si and FA blocks, respectively. Similarly, diblock copolymers were denoted as EGx-FAz. Two sets of diblock copolymers and one set of pentablock copolymers were prepared, in which the length of the fluorinated block was increased by increasing the initial monomer/macroinitiator mole ratio $\left([\mathrm{M}]_{0} /[]_{0}\right)$. This allowed for creation of block copolymers with a varied amphiphilic character that was tuned by the ATRP.

Figure 1 illustrates the kinetic plot of $\ln \left([\mathrm{M}]_{0} /[\mathrm{M}]\right)$ vs time for ATRP of FA initiated by the difunctional macroinitiator Si5- $(\mathrm{EG} 7 \mathrm{Br})_{2}$ for $[\mathrm{M}]_{0} /[\mathrm{I}]_{0}=16$. The plot has a linear trend up to conversions of $\sim 80 \%\left(\mathrm{R}^{2}=\right.$ 0.9711), indicating that the polymerization proceeded with an approximately constant number of active species in the first 120 min of reaction. Deviation from linearity may be due to a limited control of the polymerization at longer reaction times. The number average degrees of polymerization $(z)$ of the FA block as determined by ${ }^{1} \mathrm{H}$ NMR were consistent with the theoretical values of an ATRP calculated by Eq. $[1]:^{44}$

$$
2 z=p \frac{[M]_{0}}{[I]_{0}}
$$

where $p$ is the monomer conversion and $[\mathrm{M}]_{0}$ and []$_{0}$ are the initial molar concentrations of monomer and macroinitiator, respectively. Figure 2 shows the evolution of the $M_{\mathrm{n}}$ as a function of conversion $p$.

\section{[SCHEME 1] [FIGURE 1] [FIGURE 2]}

The formation of block copolymer structures was confirmed by ${ }^{19} \mathrm{~F}$ NMR investigations, which proved the attachment of the FA polymer block. The chemical composition of the copolymers was evaluated 
from the integrated areas of the ${ }^{1} \mathrm{H}$ NMR signals at $4.4 \mathrm{ppm}\left(\mathrm{COOCH}_{2}\right.$ of $\left.\mathrm{FA}\right)$ and $3.3 \mathrm{ppm}\left(\mathrm{OCH}_{3}\right.$ of EG) for the diblock copolymers or $0.1 \mathrm{ppm}\left(\mathrm{SiCH}_{3}\right.$ of $\left.\mathrm{Si}\right)$ for the pentablock copolymers. The polymer characteristics are summarized in Table 1. Generally, the SEC curves of block copolymers containing more than 10 mol\% (49 wt\%) FA were reversed with respect to that of the corresponding macroinitiator, due to the high content of FA units in the copolymer, which have a lower refractive index than that of $\mathrm{CHCl}_{3}$. Moreover, while the SEC traces of EG12-FAz were monomodal (Figure S1 Supporting Information), those of EG46-FAz richer in FA units (FA $\geq 16$ mol\%) (Figure 3) and of Si5-(EG7-FAz) 2 (Figure S2 Supporting Information) displayed a bimodal distribution. The signal at longer retention times $\left(M_{\mathrm{n}}=\right.$ 2400-2900 $\mathrm{g} \mathrm{mol}^{-1}$ ) was due to the block copolymer in its non-aggregated form, while the signal at shorter retention times $\left(M_{\mathrm{n}}=4800-8200 \mathrm{~g} \mathrm{~mol}^{-1}\right)$ was attributed to aggregated species of the block copolymer. A similar behaviour was reported in the literature for diblock copolymers of hexylethyl methacrylate and FA. ${ }^{45}$ The values of the $M_{n}$ evaluated by SEC were generally lower than those obtained by NMR. This is due to the large difference in the hydrodynamic volumes of the fluorinated block copolymers and the polystyrenes used for calibration.

\section{[FIGURE 3]}

Aggregation of the block copolymers in $\mathrm{CHCl}_{3}$ was confirmed by DLS measurements (Table 1). Average aggregate sizes $D_{\mathrm{n}}$ from 98 to $256 \mathrm{~nm}$ were detected. The aggregation is likely due to association of the fluorinated blocks, which are much less soluble in $\mathrm{CHCl}_{3}$ than the $\mathrm{EG}$ and Si blocks. Conversely, the same measurements repeated in TFT, a good solvent for fluorinated polyacrylates, did not reveal the presence of aggregated species. These results are in agreement with what was previously reported for block copolymers of poly(ethylene oxide) and perfluorohexylethyl methacrylate. ${ }^{46,47}$ It is anticipated that the diblock copolymers give rise to micelle-like structures with a fluorinated core and an oxyethylene shell. However, the pentablock copolymers seem amenable to more complex self-assemblies, ${ }^{48}$ owing to the outer location of the fluorinated block in the $A B C B A$ architecture.

\section{[TABLE 1]}

DSC analyses revealed that each set of copolymers exhibited a thermal behaviour that depended on both chemistry and composition of the block copolymer. Unlike the corresponding macroinitiator $\operatorname{EG} 12 \mathrm{Br}\left(T_{\mathrm{m}}=10^{\circ} \mathrm{C}, \Delta H_{\mathrm{m}}=-81.9 \mathrm{~J} \mathrm{~g}^{-1}\right)$, all the copolymers EG12-FAz were amorphous and showed a single glass transition temperature $\left(T_{\mathrm{g}}\right)$. In particular, EG12-FA9 displayed a $T_{\mathrm{g}}$ at around $-38{ }^{\circ} \mathrm{C}$, which was associated with the oxyethylene block. On the other hand, a $T_{\mathrm{g}}$ at $-13^{\circ} \mathrm{C}$ due to the fluorinated block was detected for copolymer EG12-FA66 with the highest content of FA (97 wt\%). Similar to the corresponding macroinitiator $\operatorname{EG} 46 \mathrm{Br}\left(T_{\mathrm{m}}=52{ }^{\circ} \mathrm{C}, \Delta H_{\mathrm{m}}=-148.0 \mathrm{~J} \mathrm{~g}^{-1}\right)$, the copolymers EG46-FAz showed 
a semicrystalline behaviour; their melting temperatures decreased in the range $24-45^{\circ} \mathrm{C}$ with increasing length of the FA block (Figure S3 Supporting Information). Moreover, EG46-FA30 and EG46-FA42, with a higher content of FA moieties ( $\geq 85$ wt\%) showed two $T_{\mathrm{g}}$ 's at $-64{ }^{\circ} \mathrm{C}$ and $-23{ }^{\circ} \mathrm{C}$ due to the EG and FA blocks, respectively. Pentablock copolymer Si5-(EG7-FA5) 2 possessed two glass transitions centered at $108{ }^{\circ} \mathrm{C}$ and $-48{ }^{\circ} \mathrm{C}$ which correlated well with those detected for the corresponding macroinitiator Si5$(\mathrm{EG} 7 \mathrm{Br})_{2}\left(T_{\mathrm{g}}{ }^{\prime} \mathrm{S}\right.$ at $-119{ }^{\circ} \mathrm{C}$ and $\left.-69^{\circ} \mathrm{C}\right)$ due to the siloxane and oxyethylene blocks, respectively (Figure S4 Supporting Information). For Si5-(EG7-FA10) ${ }_{2}$ an additional $T_{\mathrm{g}}$ at $-27^{\circ} \mathrm{C}$ attributable to the fluorinated block was also recorded.

\section{Preparation of coatings for biological assays}

Two-layer coatings for tests with the macroalga $U$. linza were prepared following a previous procedure. ${ }^{27} \mathrm{~A}$ thin layer $(\sim 2 \mu \mathrm{m})$ of the surface-active copolymer blended with the PDMS matrix in two different loadings, $w=4$ and $8 w t \%$ with respect to PDMS, was spray-coated on a thicker bottom layer $(\sim 150-200 \mu \mathrm{m})$ of the matrix itself. The blend composition was intentionally kept low $(\leq 8 \mathrm{wt} \%)$ in order to prevent oversaturation of the film surface by the block copolymer, which would result in an actual depletion in fluorine of the outer surface layers. ${ }^{49,50}$ The PDMS bottom layer was necessary to impart the desired bulk thickness and elastic modulus to the overall system. A relatively large thickness (150-200 $\mu \mathrm{m})$ and a low elastic modulus $\left(E^{\prime} \sim 2 \mathrm{MPa}\right)$ have been shown to favour the release of several macrofoulers, including $U$. linza. ${ }^{31,51}$ Condensation among the silanol groups of PDMS matrix and glass surface ensured firm anchorage by covalent bonding of the coating to the substratum, thereby preventing delamination during prolonged under-water evaluations.

The surface-active polymers of choice were pentablock copolymers, for which the siloxane central block provided compatibility with the matrix. Coatings containing PDMS either alone or with the nonfluorinated macroinitiator $\mathrm{Si5}-(\mathrm{EG} 7 \mathrm{Br}) 2$ were also prepared as controls.

One-layer coatings were prepared for protein adsorption investigations. A solution of the block copolymer alone or blended with the PDMS matrix was directly spin-coated on previously silanized glass slides to obtain thin films $(\sim 500 \mathrm{~nm})$. Silanization of the glass substrate was necessary to ensure good film formation. Copolymers of choice were EG12-FA9, EG46-FA30, Si5-(EG7-FA5)2, taken as representative samples of each class of block copolymers. Moreover, pentablock copolymers Si5-(EG7$\mathrm{FA5})_{2}$ and Si5-(EG7-FA10) ${ }_{2}$ were used to prepare one-layer PDMS-matrix coatings according to the same formulation ( $w=4$ and $8 w t \%$ with respect to PDMS) as the top layer in the two-layer coatings. Coatings 
containing PDMS alone or with the non-fluorinated $\mathrm{Si5}-(\mathrm{EG} 7 \mathrm{Br})_{2}$ macroinitiator were also prepared as controls.

In both coating geometries, the block copolymer was physically dispersed, i.e. not chemically linked, within the PDMS matrix in a semi-interpenetrating crosslinked network. The crosslinking reaction of the PDMS matrix occurred via a condensation sol-gel process at room temperature, that was catalyzed by bismuth neodecanoate. ${ }^{27}$ This catalyst has recently been shown to be less toxic than tin-based catalysts in laboratory assays against several marine species. ${ }^{27}$ Final cure was carried out at $120{ }^{\circ} \mathrm{C}$. At this temperature the block copolymer migration to the surface was also facilitated. No polymer leaching out of the coatings was detected in the extraction waters.

\section{Static contact angle and surface tension of coatings}

The contact angles for all films submitted to biological assays were measured with both water and $n$ hexadecane $\left(\theta_{\mathrm{w}}, \theta_{\mathrm{h}}\right)$. The $\theta$ values for the two PDMS-matrix systems were comparable and substantially independent of the coating geometry and thickness and of the deposition technique (Table S1 Supporting Information). Therefore, only the $\theta$ measured for two-layer coatings will be discussed in detail (Table 2). Isopropanol was also used as a polar wetting liquid for pentablock copolymers and their PDMS-matrix coatings, given its capability to discriminate more selectively between fluorine-rich and silicon-rich surface phases than do other wetting liquids that are normally used to measure $\theta$ of polymer films. $^{13,52}$

Fluorinated coatings exhibited relatively high values of contact angles with both water $\left(105^{\circ} \leq \theta_{\mathrm{w}} \leq 110^{\circ}\right)$ and $n$-hexadecane $\left(64^{\circ} \leq \theta_{\mathrm{h}} \leq 71^{\circ}\right)$, consistent with the existence of a film surface that was simultaneously hydrophobic and lipophobic. Generally, $\theta_{\mathrm{w}}$ and $\theta_{\mathrm{h}}$ were essentially not affected by copolymer composition and its content in the blends. Similarly, the $\theta_{\mathrm{ip}}$ values $\left(58^{\circ} \leq \theta_{\mathrm{ip}} \leq 62^{\circ}\right)$ also appeared to be independent of blend formulation. Both $\theta_{\mathrm{h}}$ and $\theta_{\text {ip }}$ were much larger for the fluorinated coatings than for the coatings containing the macroinitiator Si5-(EG7Br $)_{2}$. Thus, inclusion of the fluorinated block copolymer affected the hydrophobic and especially the lipophobic character of the coatings. Moreover, $\theta_{\mathrm{h}}$ and $\theta_{\mathrm{ip}}$ values were generally close to or even higher than those of the corresponding block copolymer, e.g. Si5-(EG7-FA5) $2_{2} 4 \mathrm{~T}$ vs Si5-(EG7FA5) $)_{2}$, rather than those of the PDMS matrix. This suggests that the fluorinated block copolymer was selectively segregated to the polymer-air interface. The pristine block copolymers, having the same overall number of FA repeating units, showed high values of $\theta_{\mathrm{h}} \geq 69^{\circ}$ and relatively high values of $\theta_{\mathrm{w}}$, which increased with the FA content in the copolymer, going from $88^{\circ}$ for EG46-FA9 (16 mol\%) to $96^{\circ}$ for Si5-(EG7-FA5) 2 (34 mol\%) up to $105^{\circ}$ for 
EG12-FA9 (43 mol\%).

From $\theta_{\mathrm{w}}$ and $\theta_{\mathrm{h}}$ measurements, the values of surface tension $\gamma_{\mathrm{s}}$ were calculated by the additive component method of Owens-Wendt-Kaelble (Table 2). ${ }^{34,35}$ All the coatings with the fluorinated pentablock copolymers exhibited $\gamma_{\mathrm{S}}$ exceptionally low values $\left(13.3 \mathrm{mN} \mathrm{m}^{-1} \leq \gamma_{\mathrm{S}} \leq 15.8 \mathrm{mN} \mathrm{m}^{-1}\right)$, much lower than those of the non-fluorinated coatings. Moreover, $\gamma_{s}$ values were comparable to those of the corresponding pristine block copolymer (e.g. $\gamma_{\mathrm{S}}=14.4$ and $17.7 \mathrm{mN} \mathrm{m}^{-1}$ for Si5-(EG7-FA5) 2 _ 8T and Si5(EG7-FA5) 2 , respectively) and were not affected to a significant extent by changes in the formulation of the coating. In any case, the dispersion component of $\gamma_{\mathrm{s}}$ provided a predominant contribution $\left(\gamma_{\mathrm{S}}{ }^{\mathrm{d}} \geq 12.1\right.$ $\left.\mathrm{mN} \mathrm{m}{ }^{-1}\right)$, with the polar component being generally minimal $\left(\gamma_{\mathrm{s}}^{\mathrm{p}} \leq 2.0 \mathrm{mN} \mathrm{m}^{-1}\right)$ and lower than that of the corresponding pentablock copolymer. Probably the EG blocks were segregated in the underneath surface region more effectively in the PDMS-matrix coatings than in the pristine pentablock copolymers. For the copolymers EG12-FA9, EG46-FA9 and Si5-(EG7-FA5) 2 , the polar component $\gamma_{\mathrm{s}}^{\mathrm{p}}$ markedly increased with the content of EG and was comparable to $\gamma_{s}{ }^{d}$ for EG46-FA9 with the highest content of EG units. Therefore, the polar interactions between the liquid and the EG block became significant.

In order to evaluate the coating surface stability when immersed in water, contact angles of one-layer and two-layer coatings were measured after $2 \mathrm{~h}$ and 7 days of immersion, in view of their use for biological assays with proteins and alga, respectively. Generally, $\theta$ values measured for one-layer coatings tended to increase after $2 \mathrm{~h}$ of immersion (Table 2, results reported only for pristine block copolymers). On the other hand, $\theta_{\mathrm{w}}$ and $\theta_{\mathrm{ip}}$ values measured for two-layer coatings were found to decrease after immersion in water for 7 days. This is consistent with the amphiphilic nature of the pentablock copolymers, where the hydrophilic oxyethylene chains interact with water, thereby causing a surface reconstruction of the wet films. Nevertheless, $\theta_{\mathrm{w}}$ was $>90^{\circ}$ and the surfaces retained their hydrophobicity in spite of the reconstruction. $\theta_{\mathrm{h}}$ was affected differently and tended to increase for the fluorinated coatings. These two opposite trends resulted in a slight increase in $\gamma_{s}$ by maximum $2.0 \mathrm{mN} \mathrm{m}^{-}$ 1

\section{[TABLE 2]}

\section{Surface composition of coatings}

A chemical analysis of the film surfaces was performed by angle-resolved XPS on one-layer coatings at two different photoemission angles (the angle between the surface normal and the path taken by electrons toward the detector), $\phi=70^{\circ}$ and $20^{\circ}$. For diblock copolymer films, the survey spectra showed the signals due to the elements constituting the repeating units, which were centered at: C (1s) at 290 
$\mathrm{eV}, \mathrm{O}(1 \mathrm{~s})$ at $533 \mathrm{eV}$ and $\mathrm{F}$ with (1s) and (2s) transitions at $689 \mathrm{eV}$ and $40 \mathrm{eV}$, respectively. The survey spectra of pentablock copolymers and related PDMS blends revealed the presence only of Si (2p) and (2s) transitions at $102 \mathrm{eV}$ and $153 \mathrm{eV}$, respectively, in addition to F, O and C (Figure 4). The C (1s) signal was generally structured in several components due to the presence of chemically different $\mathrm{C}$ atoms (Figure 5).

Quantitative results are discussed in detail for EG12FA9 and Si5-(EG7-FA5) 2, taken as examples of diblock and pentablock copolymers, respectively, and for the PDMS-matrix coatings Si5-(EG7-FA5) 2440 , Si5$\left(\right.$ EG7-FA10) $2_{2} 40$ and Si5-(EG7-FA10) 2_80. The elemental analysis data at the different angles $\phi$ are summarized in Table 3. For comparison, the theoretical values are also reported for the ideal homogeneous block copolymers and their blends with PDMS.

\section{[FIGURE 4] [FIGURE 5]}

Surprisingly, the diblock and pentablock copolymers presented a similar surface composition independent of their different macromolecular architecture. In both copolymer systems, the experimental $\mathrm{F}$ percentage was much higher than the theoretical value and even slightly higher than that calculated for a surface completely covered by FA ( $F=50 \%, O=8 \%$ and $C=42 \%)$. The outer surface was highly enriched in $\mathrm{F}$ because of the strong and selective migration of the perfluorohexyl chains to the polymer-air interface. The fluorine segregation appeared less effective at increased sampling depth, e.g. F passed from $52.4 \%\left(\phi=70^{\circ}\right)$ to $44.4 \%\left(\phi=20^{\circ}\right)$ for Si5-(EG7-FA5) $\left(F_{\text {theor }}=39.5 \%\right)$. Accordingly, the oxyethylene and siloxane blocks preferably populated the layers underneath.

The previous remarks are also valid for the PDMS coatings containing the pentablock copolymers (Table 3). All the films displayed surface compositions very similar to each other and essentially independent of the length of the fluorinated block and its content in the PDMS matrix. However, the surface segregation of the fluorinated block was more effective than for the corresponding pentablock copolymer, being the

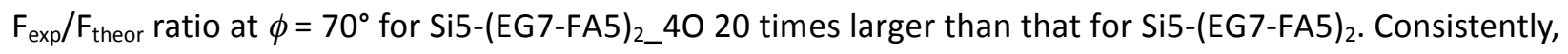
the $\mathrm{C}$ (1s) peaks arising from the $\mathrm{CF}_{2}$ and $\mathrm{CF}_{3}$ groups at $291.3 \mathrm{eV}$ and $293.6 \mathrm{eV} \mathrm{eV}$, respectively (Figure 5), were much greater (33.9\% and $7.4 \%$ at $\phi=70^{\circ}$, respectively) than the stoichiometric percentage (1.5\% and $0.3 \%$, respectively). The $\mathrm{F}_{\mathrm{exp}} / \mathrm{F}_{\text {theor }}$ ratio decreased with increased length of the FA block in the copolymer $\left(F_{\text {exp }} / F_{\text {theor }} \sim 28\right.$ for Si5-(EG7-FA5) 2_4O and $\sim 24$ for Si5-(EG7-FA10) 2_4O) and its loading in the PDMS blend $\left(F_{\text {exp }} / F_{\text {theor }} \sim 24\right.$ for Si5-(EG7-FA10) 2_40 and $\sim 13$ for Si5-(EG7-FA10) 2_80). Moreover, it should be stressed that Si percentages were in any case dramatically lower than the theoretical ones, being the ratio $\mathrm{Si}_{\text {exp }} / \mathrm{Si}_{\text {theor }}=0.08$ much lower that that obtained for the pristine block copolymer $\left(\mathrm{Si}_{\text {exp }} / \mathrm{Si}_{\text {theor }}=0.2\right.$ at $\left.\phi=70^{\circ}\right)$. To investigate the effects of the amphiphilic nature of the coating on surface 
chemical composition an angle-dependent XPS analysis was also carried out on selected PDMS-matrix coatings, Si5-(EG7-FA10) $2_{2} 80$ and Si5-(EG7-FA8) $2_{-} 40$, after immersion in water for 7 days (Table 3). The elemental composition varied with $\phi$ and the $\mathrm{F}$ atomic percentage followed the same trend as for the surfaces before immersion in water. However, for both PDMS-matrix coatings, the experimental $F$ percentage decreased, while the $\mathrm{C}, \mathrm{O}$, and Si percentages increased, after immersion in water relative to the respective dry surfaces. This trend was more marked for Si5-(EG7-FA8) $2_{2} 40$ with the shorter FA block and the lower copolymer loading in the blend. A surface rearrangement had occurred which involved the migration of the fluorinated chains into the bulk of the film and a concomitant major exposure of the oxyethylene and siloxane chains to the polymer-water interface.

[TABLE 3]

\section{HSA protein adsorption}

The amount of HSA adsorbed on test surfaces is reported in Figure 6. Protein adsorption on fluorinated PDMS-matrix coatings was similar to that of the PDMS control and markedly higher than that on glass ( $p$ $<$ 0.05). Moreover, adhesion appeared to increase with the block copolymer loading (cf. Si5-(EG7$\mathrm{FAz})_{2} 4 \mathrm{O}$ and Si5-(EG7-FAz $\left.)_{2} 8 \mathrm{O}\right)$ and decrease with the length of the FA block for a given formulation (cf. Si5-(EG7-FA5) 2_4O and Si5-(EG7-FA10) 2_4O). However, these differences were not significant. On the other hand, HSA detected on pristine block copolymer films EG46-FA30 and EG12-FA9 was much lower than on glass $(p<0.001)$. Moreover, significant differences $(p<0.05)$ were observed between pentablock Si5-(EG7-FA5) 2 and diblock EG46-FA30 copolymers. The latter, having the highest content of EG units, was the best performing sample in terms of inhibiting HSA adhesion.

\section{[FIGURE 6] [FIGURE 7]}

Confocal analysis on the same samples incubated with HSA-FITC qualitatively showed the different protein distribution on test surfaces (Figure 7). While the pentablock copolymer film Si5-(EG7-FA5) 2 displayed a homogeneous distribution, the corresponding PDMS-matrix coatings showed a heterogeneous distribution with high protein adsorption areas (green) alternating with areas where proteins had not adhered (black). The diblock copolymer films EG46-FA30 and EG12-FA9 exhibited a totally black surface, as there were no adhered proteins. These findings are in agreement with the quantitative HSA assays. Although we cannot exclude the existence of a sub-microscopic phase separation of the block copolymer in the near-surface regions, HSA and HSA-FITC proteins appeared to be more effectively adsorbed on even slightly PDMS-populated regions. 


\section{Calf serum protein adsorption}

With the aim of evaluating the biological environment in vivo, adsorption assays were carried out using a complex protein solution, i.e. calf serum. Samples incubated with calf serum showed a similar trend of protein adsorption as that with HSA (Figure 8). In particular, the amount of protein on PDMS-matrix coatings containing the fluorinated pentablock copolymers was not significantly different from that detected on the unfluorinated controls. Moreover, protein adsorption on Si5-(EG7-FA5) 2 _4O and Si5(EG7-FA10)2_80 was significantly higher than that on glass $(p<0.05)$. No general trend was observed for coatings with the same amount of copolymer in the blend, but varied length of the FA block. The pristine pentablock copolymer Si5-(EG7-FA5) 2 showed a lower protein adhesion than the corresponding PDMS blend Si5-(EG7-FA5) $2_{2} 40(p<0.05)$ and a significantly lower protein repellence than EG12-FA9 $(p$ $<0.001$ ) and EG46-FA30 ( $p<0.05$ ). EG12-FA9 was the most protein-resistant film.

\section{[FIGURE 8]}

Overall the results indicate a higher protein adsorption on all the surfaces of the PDMS-matrix coatings with or without fluorinated pentablock copolymer. This is possibly due to favourable interactions of proteins with hydrophobic PDMS, ${ }^{53}$ which is prone to protein adhesion. ${ }^{54}$ The pentablock copolymer alone had consistently higher protein-resistance properties than the PDMS coatings, but much lower than the diblock copolymers not containing the siloxane block. In a previous study the protein adsorption on a diblock copolymer containing PDMS and zwitterionic polymer segments was shown to be specific to the hydrophobic PDMS regions. ${ }^{55}$ Moreover, the oxyethylene units present in all the block copolymers, and especially in the diblock copolymers, were also responsible for weaker interactions between the proteins and the polymer surface. In fact hydrophilic oxyethylene surfaces resist nonspecific protein adsorption, ${ }^{56}$ owing to their capability to tightly bind water molecules in a surface hydration layer that creates a stable structure on the hydrophilic surface and serves as a physical barrier resisting protein adsorption. ${ }^{53,57}$

\section{Assays with U. linza}

The AF and FR performances were tested in laboratory bioassays with the marine green macroalga $U$. linza. AF performance was determined by quantifying the number of zoospores that settled (attached) to the surfaces within a standard period of time. FR performance was assessed by measuring the ease of removal of sporelings (young plants) grown on the test surfaces by exposure to a calibrated shear stress. The mean density of spores settled to the test surfaces is shown in Figure 9a. One way analysis of variance with Tukey's test showed that all the experimental coatings had a higher density of spores than 
the PDMS control $(F 7,712=140.4 p<0.05)$. Increasing the content of the macroinitiator Si5- $(\mathrm{EG} 7 \mathrm{Br})_{2}$ from 4 to $8 \mathrm{wt} \%$, which resulted in an increase in oxyethylene units, caused a reduction in spore settlement density. The spore density was essentially the same independent of the length of the FA block at a given copolymer loading. By contrast, increasing the loading of the pentablock copolymer in the matrix, which corresponded to an increase in the concentration of the fluorinated units, enhanced spore settlement. These results are consistent with previously reported studies, which showed that spores settled more on fluorinated rather than on PEGylated surfaces. ${ }^{12,39}$

Sporelings grew well on all surfaces and after 7 days a green lawn covered the surface of all samples. The percentage release of biomass after exposure to a wall shear stress of $13 \mathrm{~Pa}$ in a flow channel is shown in Figure 9b. One way analysis of variance on arcsine transformed data with Tukey's test showed that significantly more biomass was removed (up to 70\%) from three of the coatings containing the fluorinated pentablock copolymers (Si5-(EG7-FA10) 2_8T, Si5-(EG7-FA5) 2_4T Si5-(EG7-FA5) 2_8T) compared to the PDMS control (4\%) (F 7, $39=21 p<0.05)$. Despite the higher spore settlement density on these three coatings, the biomass remaining after exposure to the shear stress was less than half that on the PDMS control (Table S2 Supporting Information). Percent removal from the Si5-(EG7-FA10) 24 4T fluorinated pentablock copolymer was lower than from the other fluorinated coatings. Removal from the non-fluorinated films was similar to that from the PDMS control. Except for Si5-(EG7-FA10) 24 4T coating, the addition of the fluorinated pentablock copolymer resulted in a significant improvement of fouling release properties, independent of the relative length of FA in the copolymer and its loading in the matrix.

\section{[FIGURE 9]}

\section{CONCLUDING REMARKS}

Novel ABCBA-type block copolymers were synthesized via ATRP so that the length of the outer fluorinated block was adjusted to modulate the amphiphilic nature. Moreover, the presence of the central siloxane block allowed for dispersion of the copolymers as surface-active components in a (crosslinked) PDMS-matrix coating in various loadings. In such a design, the fluorinated chains could very effectively segregate to the outer surface regions of the coatings, whereas the PDMS matrix was hidden in the underlying near-surface regions, despite being the largely major component. The surfaces remained rich in fluorinated chains even after surface reconstruction after immersion in water for 7 days. It is noteworthy that the chemistry of the block copolymer and the formulation of the coating reflected in different trends of protein adsorption and algal settlement/release. Protein adsorption was 
in fact enhanced on PDMS-matrix coatings, with the diblock copolymers, not-containing a siloxane component, being most protein resistant. On the other hand, spore settlement was also higher on PDMS-matrix coatings and increased with the loading of the pentablock copolymer, i.e. with the amount of fluorinated units in the formulation. However, the coatings with the highest loading (8 wt\%) of pentablock copolymer performed much better than the unfluorinated controls for the release of sporelings of $U$. linza, their percent removal being at least 17 -fold larger than that for PDMS. Thus, the biological results clearly point to a potential of PDMS-matrix coatings containing amphiphilic pentablock copolymers as fouling release coatings.

\section{ACKNOWLEDGMENTS}

This work was supported by the EC Framework 7 SEACOAT project (Surface Engineering for Antifouling: Coordinated Advanced Training) and the Italian MiUR (PRIN fondi 2010-2011). The authors also thank Dr. A. Glisenti (University of Padova) for assistance with the XPS experiments.

\section{REFERENCES}

1. R. L. Townsin, Biofouling 2003, 19, 9-15.

2. J. S. Vrouwenvelder, C. Hinrichs, W. G. J. V. der Meer, M. C. M. V. Loosdrecht, J. C. Kruithof, Biofouling 2009, 25, 543-555.

3. C. Werner, M. F. Maitz, C. J. Sperling, Mater. Chem. 2007, 17, 3376-3384.

4. R. E. Kania, G. E. M. Lamers, N. van de Laar, M. Dijkhuizen, E. Lagendijk, P. T. B. Huy, P. Herman, P. H. Lemstra, J. J. Grote, J. Frijns, G.V. Bloemberg, Biofouling 2010, 26, 519-526.

5. M. P. Schultz, J. A. Bendick, E. R. Holm, W. M. Hertel, Biofouling 2011, 27, 87-98.

6. I. Fitridge, T. Dempster, J. Guenther, R. de Nys, Biofouling 2012, 28, 649-669.

7. E. Pinori, M. Berglin, L. M. Brive, M. Hulander, M. Dahlström, H. Elwing, Biofouling 2011, 27, 941-953.

8. D. M. Yebra, S. Kiil, K. Dam-Johansen, Prog. Org. Coat. 2004, 50, 75-104.

9. S. Sonak, P. Pangam, A. Giriyan, K. Hawaldar, J. Environ. Manag. 2009, 90, S96-S108.

10. K. V. Thomas, S. Brooks, Biofouling 2010, 26, 73-88.

11. M. Lejars, A. Margaillan, C. Bressy, Chem. Rev. 2012, 112, 4347-4390.

12. S. Krishnan, N. Wang, C. K. Ober, J. A. Finlay, M. E. Callow, J. A. Callow, A. Hexemer, K. E. Sohn, E. J. Kramer, D. A. Fischer, Biomacromolecules 2006, 7, 1449-1462. 
13. I. Marabotti, A. Morelli, L. M. Orsini, E. Martinelli, G. Galli, E. Chiellini, E. M. Lien, M. E. Pettitt, M. E. Callow, J. A. Callow, S. L. Conlan, R. J. Mutton, A. S. Clare, A. Kocijan, C. Donik, M. Jenko, Biofouling 2009, 25, 481-493.

14. Y. Wang, D. E. Betts, J. A. Finlay, L. Brewer, M. E. Callow, J. A. Callow, D. E. Wendt, J. M. De Simone, Macromolecules 2011, 44, 878-885.

15. P. Majumdar, S. Stafslien, J. Daniels, D. C. Webster, J. Coat. Technol. Res. 2007, 4, 131-138.

16. S. Sommer, A. Ekin, D. C. Webster, S. J. Stafslien, J. Daniels, L. J. Van der Wal, S. E. M. Thompson, M. E. Callow, J. A. Callow, Biofouling 2010, 26, 961-972.

17. S. Jiang, Z. Cao, Adv. Mater. 2010, 22, 920-932.

18. A. Beigbeder, P. Degee, S. L. Conlan, R. J. Mutton, A. S. Clare, M. E. Pettitt, M. E. Callow, J. A. Callow, P. Dubois, Biofouling 2008, 24, 291-302.

19. C. Carl, A. J. Poole, M. J. Vucko, M. R. Williams, S. Whalan, R. de Nys, Biofouling 2012, 28, 1077-1091.

20. J. A. Callow, M. E. Callow, Nat. Commun. 2011, 2, doi:10.1038/ncomms1251.

21. C. S. Gudipati, C. M. Greenlief, J. A. Johnson, P. Prayongpan, K. L. Wooley, J. Polym. Sci. Part A: Polym. Chem. 2004, 42, 6193-6208.

22. K. T. Powell, C. Cheng, K. L. Wooley, Macromolecules 2007, 40, 4509-4515.

23. Y. Wang, L. M. Pitet, J. A. Finlay, L. H. Brewer, G. Cone, D. E. Betts, M. E. Callow, J. A. Callow, D. E. Wendt, M. A. Hillmyer, J. M. De Simone, Biofouling 2011, 27, 1139-1150.

24. E. Martinelli, S. Agostini, G. Galli, E. Chiellini, A. Glisenti, M. E. Pettitt, M. E. Callow, J. A. Callow, K. Graf, F. W. Bartels, Langmuir 2008, 24, 13138-13148.

25. Z. Zhou, D. R. Calabrese, W. Taylor, J. A. Finlay, M. E. Callow, J. A. Callow, D. Fischer, E. J. Kramer, C. K. Ober. Biofouling 2014, 30, 589-604.

26. E. Martinelli, M. K. Sarvothaman, M. Alderighi, G. Galli, E. Mielczarski, J. A. Mielczarski. J. Polym. Sci. Part A: Polym. Chem. 2012, 50, 2677-2686.

27. C. Pretti, M. Oliva, E. Mennillo, M. Barbaglia, M. Funel, B. R. Yasani, E. Martinelli, G. Galli, Ecotoxicol. Environ. Saf. 2013, 98, 250-256.

28. M. L. Hawkins, F. Fay, K. Rehel, I. Linossier, M. A. Grunlan, Biofouling, 2014, 30, 247-258.

29. C. S. Gudipati, J. A. Finlay, J. A. Callow, M. E. Callow, K. L. Wooley, Langmuir 2005, 21, 3044-3053.

30. E. Martinelli, M. Suffredini, G. Galli, A. Glisenti, M. E. Pettitt, M. E. Callow, J. A. Callow, D. Williams, G. Lyall, Biofouling 2011, 27, 529-541. 
31. M. K. Chaudhury, J. A. Finlay, J. Y. Chung, M. E. Callow, J. A. Callow, Biofouling 2005, 21, 4148.

32. C. J. Weinman, J. A. Finlay, D. Park, M. Y. Paik, S. Krishnan, H. S. Sundaram, M. Dimitriou, K. E. Sohn, M. E. Callow, J. A. Callow, D. L. Handlin, C. L. Willis, E. J. Kramer, C. K. Ober, Langmuir 2009, 25, 12266-12274.

33. J. Kim, B. J. Chisholm, J. Bahr, Biofouling 2007, 23, 113-120.

34. D. K. Owens, R. C. Wendt, J. Appl. Polym. Sci. 1969, 13, 1741-1747.

35. D. H.Kaelble, J. Adhesion 1970, 2, 66-81.

36. D. A. Shirley, Phys. Rev. B 1972, 5, 4709-4714.

37. J. F. Moulder, W. F. Stickle, P. E. Sobol, K. D. Bomben, Handbook of X-ray Photoelectron Spectroscopy. 1992. Eden Prairie (MN): Physical Electronics.

38. M. E. Callow, J. A. Callow, J. D. Pickett-Heaps, R. Wetherbee, J. Phycol. 1997, 33, 938-947.

39. I. Thomé, M. E. Pettitt, M. E. Callow, J. A. Callow, M. Grunze, A. Rosenhahn, Biofouling 2012, 28, 501-510.

40. R. C. Starr, J. A. Zeikus, J. Phycol. 1987, 23, S1-S27.

41. S. Mieszkin, P. Martin-Tanchereau, M. E. Callow, J. A. Callow, Biofouling 2012, 28, 953-968.

42. M. P. Schultz, J. A. Finlay, M. E. Callow, J. A. Callow, Biofouling 2000, 15, 243-251 and Biofouling 2003, 19, 17-26.

43. K. Huan, L. Bes, D. M. Haddleton, E. Khoshdel, J. Polym. Sci., Part A: Polym. Chem. 2001, 39, $1833-1842$

44. K. Matyjaszewski, J. Xia, Chem. Rev. 2001, 101, 2921-2990.

45. Y. Zhu, W. T. Ford, Macromolecules 2008, 41, 6089-6093.

46. K. T. Lim, M. Y. Lee, M. J. Moon, G. D. Lee, S.-S. Hong, J. L. Dickson, K. P. Johnston, Polymer 2002, 43, 7043-7049.

47. H. Hussain, K. Busse, J. Kressler, Macromol. Chem. Phys. 2003, 204, 936-946.

48. M. Niu, L. He, J. Liang, A. Pan, X. Zhao, Prog. Org. Coat. 2014, 77, 1603-1612.

49. W. Zhang, Y. Zheng, L. Orsini, A. Morelli, G. Galli, E. Chiellini, E. E. Carpenter, K. J. Wynne, Langmuir, 2010, 26, 5848-5855.

50. J. A. Mielczarski, E. Mielczarski, G. Galli, A. Morelli, E. Martinelli, E. Chiellini, Langmuir 2010, $26,2871-2876$.

51. B. R. Yasani, E. Martinelli, G. Galli, A. Glisenti, S. Mieszkin, M. E. Callow, J. A. Callow, Biofouling 2014, 30, 387-399. 
52. E. Martinelli, A. Glisenti, B. Gallot, G. Galli, Macromol. Chem. Phys. 2009, 210, 1746-1753.

53. H. S. Sundaram, Y. Cho, M. D. Dimitriou, C. J. Weinman, J. A. Finlay, G. Cone, M. E. Callow, J. A. Callow, E. J. Kramer, C. K. Ober, Biofouling 2011, 27, 589-602.

54. Z. Zhang, X. Feng, Q. Luo, B. F. Liu, Electrophoresis 2009, 30, 3174-3180

55. J. H. Seo, R. Matsuno, M. Takai, K. Ishihara, Biomaterials 2009, 30, 5330-5340.

56. P. Gasteier, A. Reska, P. Schulte, J. Salber, A. Offenhusser, M. Moeller, J. Groll, Macromol. Biosci. 2007, 7, 1010-1023.

57. Y. Cho, H. S. Sundaram, J. A. Finlay, M. D. Dimitriou, M. E. Callow, J. A. Callow, E. J. Kramer, C. K. Ober, Biomacromolecules 2012, 13, 1864-1874.

\section{CAPTION TO FIGURES}

SCHEME 1. Synthesis of ATRP diblock copolymers EGx-FAz.

SCHEME 2. Synthesis of ATRP pentablock copolymers Siy- $(E G x-F A z)_{2}$.

FIGURE 1. Semilogarithmic kinetic plot for the ATRP of FA initiated by Si5-(EG7Br $)_{2}\left([\mathrm{M}]_{0} /[\mathrm{I}]_{0}=16\right)$.

FIGURE 2. Plot of $M_{\mathrm{n}}$ vs. conversion for the ATRP of FA initiated by $\mathrm{Si5}-(\mathrm{EG7Br})_{2}\left([\mathrm{M}]_{0} /[1]_{0}=16\right)$.

FIGURE 3. SEC traces of the macroinitiator EG46Br and the corresponding diblock copolymers EG46-FAz.

FIGURE 4. XPS survey spectra for the coating Si5-(EG7-FA5) $2_{-} 40$ at $\phi=70^{\circ}$ and $20^{\circ}$.

FIGURE 5. Normalized C (1s) XPS spectrum for coating Si5-(EG7-FA5) $2_{-} 40$ at $\phi=70^{\circ}$ (with assignments to the main contributing moieties).

FIGURE 6. HSA adsorption on test surfaces (mean \pm SD on three replicates; ${ }^{*} p<0.05,{ }^{* *} p<0.001$ ).

FIGURE 7. Fluorescence images of adsorbed HSA-FITC (scale bar represents $100 \mu \mathrm{m}$ ).

FIGURE 8. Calf serum protein adsorption on test surfaces (mean \pm SD on three replicates; $* p<0.05, * *$ $\mathrm{p}<0.001)$.

FIGURE 9. (a) Mean number of $U$. linza spores attached after 45 min settlement period (mean of 90 counts, 30 from each of 3 replicates. Error bars show 95\% confidence limits); (b) Percent removal of sporelings of $U$. linza by exposure to a wall shear stress of $13 \mathrm{~Pa}$ (each point is the mean of 6 replicates; error bars represent standard error of the mean from arc-sine transformed data). 